\title{
The Algerian Post-Independence Linguistic Policy - a Recovery of National Identity
}

\author{
Dr. Malika Sahel
}

Ecole Nonnale Superieure/Bouzareah (E.N.S.B) Department of English

\begin{abstract}
The Arabic language and education in Algeria faced hard times under the French occupation and witnessed the dramatic decline of literacy rate among the Algerian population up to independence (1830-1962). Indeed French determined and well-planned history of domination, systematic illiteracy, linguistic and cultural alienation and socio-economic deprivation had a significant impact on the form, pace, direction and purpose of educational strategy options in post-independence Algeria. Accordingly, the planned objectives of Algerian policy were to regain identity, ensure personality growth of the young Algerian generations and lay the ground for the learning of modem technologies in order to participate in the national development and cope with economic demands of the modem world.
\end{abstract}

Keywords: Post-independence, Algeria, National identity, Linguistic policy.

\section{Introduction}

Language is the expression of a Nation's culture as well as a means of communication between peoples. It is also a support for legitimacy in former European colonies. For instance, in the multilingual context of the Maghreb, several legitimacies have been associated with different languages. The legitimacy of modernity has been connected with the French language. The Algerian post-independence policy of Arabisation has remained an attempt to transfer this legitimacy to Arabic, the official language of Algeria. The latter had been a French colony for more than a century (1830-1962) and subject to the most aggressive colonial policy of assimilation.

During this colonial era, after she had demolished the Algerian traditional educational systems, France pursued a determined policy to spread the French language through the setting up of schools with competent teachers trained to promote French political and cultural ideas. She ignored the national language and patois of Algeria in her system of education and excluded native culture from curricula in schools. Thus, the educational system provided specificity of the conqueror, a destruction of Algerian personality and cultural identity.

Therefore, once independence, Algeria tried to recover her national linguistic and cultural identity as an Arab Muslim country in which the language of the coloniser, the French, was no longer the imposed official language and a new linguistic policy, "Arabisation" was adopted to allow the Arabic language regain its legitimate place.

The purpose of the present paper is to show how contextual, social constraints have exerted a significant influence on the establishment of the prevailing linguistic situation in Algeria. To what extent could the adopted linguistic policy, highly desired by policy makers and decision holders, be successful in the presence of multiple contextual variables that have marked the Algerian speech community individually and collectively?

\section{I- Colonial Education and Algerian Cultural Alienation:}

The relation between culture and education is, indeed, a close and even an organic one as British sociologists - among others - have demonstrated. ${ }^{1}$ Through education as a whole process, culture can be transmitted to succeeding generations. Thus, wanting to make Algerians, for instance, heirs of French civilization, France had a complete control on the educational system in Algeria. After she had demolished traditional educational systems there, she imposed French education whose standards and curricula were the same as in France. This policy precisely meant the communication, transmission,

1 M. Crowder, Senegal : A Study in French Assimilation Policy, London : Institute of Race Relations, 1962, p. 1. 
acquisition of French knowledge, competences, beliefs, habits and ideals, a fact that would produce "French" Algerians, for instance, in hope that loyalty to France and whose detachment from the local environment would be secured as Algerian culture was excluded from curricula in school. In the latter, Arabic was ranked as foreign language. Besides, the teaching in these schools made no reference to Algeria as an African country and concentrated on French civilization, history and grandeur. "The French system [of education] was much more concerned with persuading children of the virtues of the colonial system and French culture". ${ }^{1}$

For instance, in conformity with the law 1883, France extended the virtues of the new schooling-system which emerged in France and with which the name of Jules Ferry was associated "laïcité, gratuité, and caractère obligatoire". ${ }^{2}$ Moreover, the 1892 decree, forbade to the Koranic schools to accept children during class-hours. Added to this, an official authorization was prerequisite if these Koranic schools were to receive children before or after their school-hours. The teaching of Arabic was officially reduced to two hours and half per week, and in most cases, this was badly organized. ${ }^{3}$ In other words, Arabic was taught as a foreign language. This new schooling system was obviously aimed at complete destruction of the Arabic language and Algerian cultural identity. It was the main tool French colonial ideology used to perfect the establishment of French cultural heritage, through the conquest of the minds, in other words, through "the spirit" as advocated by Napoleon I in his twilight reflections at St. Helena. ${ }^{4}$

Thus, whenever possible, in their imperialist expansion and thereafter, French leaders adopted both force and cultural penetration. Despite their use of the sword, they never neglected the importance of cultural invasion in view of the lasting results this could ensure. As a French deputy asked his colleagues in the 1900 : "What political operations or armed invasions was ever able, with less expense, to produce such important and lasting results ?". ${ }^{5}$ Having had as their ultimate objective the cultural and political integration of the Algerian people, the French were aggressive in this colony as were in all their colonies. ${ }^{6}$ Their policy was particularly guided by Napoleon III who realized after his defeat in the Franco-Prussian War the implications and potential involved in Napoleon l's intentions as he became aware of the usefulness of the cultural component to spread Influence. ${ }^{7}$ Thus, French education stood as a major channel through which culture could exert influence and allow the conqueror to achieve his ultimate goal, domination. In this context, the Governor of Algeria (18321833), Duc of Rovigo, declared that he saw in the propagation of education and the French language an efficient instrument to dominate Algeria. ${ }^{8}$

Thus, conceived as a threat to the Algerian own cultural and identity values, the French colonial imposed policy in Algeria met a strong opposition from the native population. For instance, parents refused to send their children to French schools, a fact that urged the French authorities to think of a more or less "flexible" policy to convince Algerian educated elite to cooperate as mediators between the French military authorities and the local population. For instance, in 1950, to achieve their control through education, the colonial power in Algeria reintroduced the pre-colonial model of Medersas (public schools) to train the Algerian preachers of the mosques, judges of the courts of justice and teachers of Arabic. However, within the colonial imposed education, the French language was introduced as a main subject. At that time, there were three Medersas in Algeria : one in the capital city of Algiers, the second one in the East of Algeria, Constantine and the third one in the West of Algeria, Tlemcen. All of the three public schools were under the control of the colonial power.

1 lbid, p. 378.

20. Carlier, F. Colonna, A. Djeghloul and M. El-Korso, Lettrés, Intellectuels et Militants en Algérie 1888-1950, Alger : Office des Publications Universitaires : 04-88, p. 6.

3 Idem.

4 "I have been forced to conquer Europe by the sword, he who comes after will conquer it by the spirit. For the spirit is always more powerful than the sword". Quoted in P. H. Coombs, The Fourth Dimension of Foreign Policy : Educational and Cultural Affairs, New York : Harper and Row, 1964, p. 79.

5 Idem.

6 M. Crowder, cp. cit p. 1.

7 P. H. Coombs, op. cit.

8 Le Duc de Rovigo (Governor of Algeria 1832-33) "Je regarde la propagation de l'instruction et de notre langue comme le moyen le plus efficace de faire des progrès à notre domination dans ce pays". Quoted in M. Benrabah. Langues et Pouvoir en Algérie : Histoire d'un Traumatisme Linguistique, Paris : Edition Séguier, 1999, p. 44. 
Such colonial linguistic strategy meant instruct in order to control. This colonial motto was embodied in the institution of bilingual schools; hence, Arabic, French colleges. The latter's number was 36 between 1850 and 1870. Therefore, in 1876, the administration of the public schools (Medersas) was delegated to civilians with close control to avoid the spread of awareness in concerns like equality, freedom and other human rights that were not respected by the colonial administration. This French fear of the spread of awareness was manifested by the General Governor of Algeria, Tirman who, in 1876, estimated that the hostility of the indigenous population (the colonised people) was measured to the degree of their instruction. ${ }^{1}$

Thus, a colonial decree of 1895 made compulsory for all candidates to the function of preachers, judges and teachers to have training at the newly settled Medersas in which the French language learning was deeply consolidated. This imposed measure resulted in a gradual multiplication of bilingual institutions expected to prepare and train collaborators and mediators for the French colonial administration. Yet, this colonial imposed cultural model continued to be resisted by the Algerians.

\section{II- The Algerian Resistance to Cultural Alienation:}

By the end of the nineteenth century, the French cultural model continued to meet resistance from the Algerians. Some of the honourable families manifested their resistance by exile to the Middle East and the remaining majority preferred illiteracy rather than cultural alienation. Indeed, a harsh opposition and struggle was led by the Algerian educated elite against the French colonial educational policy. The majority of those elite were armed with pre-colonial education they acquired in Koranic schools and Medersas of the time. They were deeply nourished with their native culture, a fact that allowed them to manifest a constant resistance against the colonial system. The latter, thus, encouraged generalisation of schooling, guaranteeing job only to individuals having been graded from the colonial educational institutions. Yet, the local population continued to see in the colonial schooling system a real threat for their cultural values and uncertain professional future and social promotion.

This Algerian clinging to their language led the colonial power to review its attitude towards the Arabic language. The latter, in theory, was given a status through an official article in 1947. It stated that Arabic constituted one of the languages of the French union and the teaching of Arabic in Algeria was to be organised. ${ }^{2}$ Yet, although the national movements gained some acknowledgement on behalf of the colonial administration, the French language remained outstandingly the main outcome of a long-established colonial system of education. As a matter of fact, many Algerian writers profited from their mastery of the French language and delivered their denouncements in the language of the coloniser. For instance, the end of the nineteenth century registered the emergence of the first publications by Algerian writers in the French language. These were mainly in form of essays and descriptions of the inhuman reality lived by Algerians. Far from any rebellion and opposition, the content called for equality and justice. Thirteen novels and three short stories were published by Algerian writers in French between 1920 and 1949. However, from 1947 onwards, the pacific tendency of the Algerian writers changed to cause a complete maturity of the political awareness. In fact, this change was mainly provoked by the slaughter committed by the colonial army in the eastern part of Algeria, namely in Setif, Guelma and Kherrata, on the $8^{\text {th }}$ May, 1945 in which 45,000 Algerians were killed while they were manifesting peacefully to remind France of her promise to give them their rights and independence if they fought for her in the Second World War (1939-1945). Those Algerian writers, who witnessed the horrors committed by the French in Algeria, denounced the colonial exploitation and the linguistic deprivation causing poverty and cultural alienation.

The cultural and linguistic conflict between the two different nations was obvious in the clear cut difference of extremely opposed civilizations, ways of life and identity traits. At the same time, the Algerian elite acknowledged that their constant resistance to the French schooling system constituted an obstacle for their emancipation. The French language, in fact, could be instrumentalised to denounce the colonial injustice, acquire knowledge and information and serve as a tool for salvation. Thus, it became prerequisite to acquire the attributes of the colonial system, namely language and culture, to prepare a fruitful struggle and face the enemy using his own weapons. In this context, one of the prominent Algerian literary

1 Quoted by M. Benrabah, ibid, p. 51.

2 lbid, p. 59. 
men of French expression, Kateb Yacine claimed that at that particular time, he felt it necessary to speak French even better than the French themselves in order to convince them that Algerians were not French. ${ }^{1}$

\section{III- Post-Independence Algerian Educational Situation and A New Linguistic Policy:}

The resistance of Algerians to the colonial system of education increased illiteracy which reached ninety percent among the Algerian population at Independence in 1962. In 1969-70, sixty three percent of men and eighty five percent of the women remained illiterate. ${ }^{2}$ Indeed, the schooling rate had been very low because the consequences of the French colonialism and seven years of bloody war in Algeria were disastrous. Some of the major results of the Algerian 1954 Revolutionary War included "8,000 villages were destroyed ; 1,000,000 dead ; 2,000,000 displaced ; 400,000 refugees ; hundreds of thousands interned and prisoners". ${ }^{3}$ Moreover, the French massive withdrawal population had damaged the structure of the Algerian economy and administration. Indeed, "the hand-over of power was not carried out in due and regular order". ${ }^{4}$ The absolute break between the old and new administration handicapped the normal functioning of the country which lacked technical staff, equipment and, most important, trained administrators. ${ }^{5}$ Algerian leaders were conscious that industrialization could only be achieved through education. Thus, the latter received a quarter of the Algerian national budget and 11 percent of the investment programme under the Four Year Plan (1970-73). ${ }^{6}$ This recognition of the key role education enjoyed in the Algerian Four Year Plan allowed "an impressive rate of expansion at all levels.... For example, the number of secondary school pupils... more than doubled to a total of 420,000 ". ${ }^{7}$ In fact, the recovery of the Algerian identity remained a crucial issue to achieve.

Indeed, at Independence, the prevailing linguistic situation needed a strong will and a political commitment to know a new direction that reflects the Algerian cultural identity that the French colonialism eradicated by imposing the French language and culture. For instance, the French language was among the languages of daily use in the newly independent Algeria. While Algerian Arabic, Berber in some areas and French were daily used, the classical Arabic was only used in Medersas. Consequently, the eradication of the French language and the administration of the Arabic language as an important pillar foundation of the Arab-Muslim Algerian nation became an objective in itself, President Houari Boumediene (1965-1978) was determined to achieve. This political leader who studied at Zitouna (Tunisia) and Al Azhar (Egypt) was well-equipped with a strong personality, an Arabic and Islamic culture, and a political will to lay down decrees and orders for the uprooting of the foreign cultural and linguistic prints France deeply cultivated in Algeria during the colonial era. His claim had a purely an Arab-Muslim dimension. Indeed, the exclusion of what remained of the colonial era was strongly felt, particularly when the linguistic policy of Arabisation was established.

Language remains the symbol of social interaction and daily communication. Aiming at a more and efficient practical social control, the Algerian Government opted for the policy of Arabisation. Thus, the Ministry of Education's intervention in the process of Arabisation resulted in a direct redefinition of a linguistic planning. There were three main levels where the government's interference, of course through the Ministry of Education, was apparent. The first one was related to the teaching methods; the second one had to do with the institution of the Classical Arabic in a functional parameter ; the third level was embodied in the linguistic lay out, namely the technical spheres in which the language was structured.

In her post-independence struggle against ignorance and illiteracy in order to progress, Algeria made schooling compulsory. This, in fact, increased the number of schooling pupils. For instance, during the decade 1965-75, the schooling rate significantly raised. In primary level, the number of enrolled pupils doubled from 1,200,000 to 2,750,000 ; in secondary schools, the number increased from 100,000 to 450,000 ; and at university level, the number of students augmented from 7000 to 50,000 . The educational system registered the Arabisation of the first years of the Primary school. In this context, the British Council reported : "complete Arabisation remain[ed] the long-term aim, but it [was] not being rushed through,

1 lbid, p. 67.

2 BW10/11, Restricted, The British Council Algeria Representative's Annual Report 1969-70, 1970, p. 2.

3 BW10/11, Confidential, Visit to Algeria, April 24-May 7,1963, Report by Mr. C. W. Fyfield - Representative Designate, 24 May 1963, p.2

$4 \mathrm{lbid}$,

6 BW10/11, Restricted, The British Council Algeria Representative's Annual Report 1970-71, 1971, p. 1.

7 BW10/11, Restricted, The British Council Algeria Representative's Annual Report 1972-73, 1973, p. 1. 
and it [was] still only in the first two years of the primary course that Arabic [was] the language of instruction". ${ }^{1}$ The remaining years continued to receive instruction in the French language. This process had to be gradual to encourage Arabisation year after year and pave the way for the elimination of bilingual classes from primary and middle schools, then from the higher education levels. At the university level, this new linguistic policy was adopted in Humanities and other fields but met difficulties to be extended to the medical and scientific studies. Yet the Government carried on exerting pressure to impose this policy. For instance, the National Pedagogical Institute for Printing Books was instructed to favour the printing of books written in Arabic to those written in French. This, in fact, aimed at the devaluation of the French language in an attempt to uproot what the coloniser planted.

In the same context, the post-independence administration took measures to weaken the status of the French language in the educational system. Thus, from 1962 to 2004, the Algerian pupils started to study the French language at the fourth year level in primary school. In addition to this, a new process named "linguistic cleaning" was started to change, whenever possible, terms and labeling from French to Arabic. By so doing, the Algerian administration consolidated the process of Arabisation. For instance, all the names of streets and important amenities the colonial administration imposed, during the colonial era, were changed into Arabic-origin names taken from the Algerian historical patrimony. As illustrations, Street Michelet became Didouche Mourad and Street Isly became Larbi Ben M'Hidi. This environmental and social context's Arabisation strengthened the position of classical Arabic. Yet, the proportion of francophone Algerian population remained significant. For instance, it was estimated to 49 percent (27,3 million inhabitants) in 1993 and was expected to reach 67 percent by $2003 .^{2}$

Thus, despite the tremendous efforts Algeria devoted to make of Arabisation a successful process in the quickest possible time, the French language continued to exert an influence on the Algerian society. Several factors contributed to maintain that expansion. Among these one can refer to the number of Algerian emigrants in France. More than 800,000 emigrants in France, in tight relation with their families and relatives in Algeria helped the promotion of the French language. In the same context, the French Magazine, 'Esprit', estimated that 9 to 12 million Algerians were among the French TV channels (TF1, France 2, Canal,$+ \ldots$ ) watchers. ${ }^{3}$

On the other hand, the colonial educational shaping of the educator, the text-book and the teaching model contributed to lower proficiency in the Arabic language. Post 1962 teacher lacked competence, academic training and motivation as well as academic qualifications in terms of pedagogy of teaching. Besides, the provided text-books were characterized by disparities. For instance, in 1966, the Ministry of Education reported that pupils at Secondary School level lacked the rudimentary components of a basis in classical Arabic. To remedy this alarming educational situation, it was conceived that Algerian teachers would better teach Algerian pupils, since they could understand pupils using their mother tongue, to reach the needs and interests of the Algerian population of learners. Besides this, their knowledge of the Algerian context could be instrumental. Hence, teachers from the Middle East were gradually thanked to leave their posts for Algerians. For instance, in 1969, there were 1500 Egyptian teachers in Algeria.

As to the problem of disparity in text-books, the option was to guarantee their uniformity. Yet, the absence of specified methods in the process of teaching Classical Arabic was a serious pedagogical problem in newly independent Algeria. In this context, in 1973, Taleb Ibrahimi (the then Minister of Culture and previously Minister of National Education in 1965) claimed that the Arabisation as a fundamental option constituted an objective that required precision. ${ }^{4}$ This lack of objectivity was the result of the post-independence ideological choice of Arabisation and political will that wanted to detach Algeria from France by distinguishing Algerian teaching from what it used to be during the colonial era. ${ }^{5}$

However, the favoured treatment Algeria has always manifested towards the educational field by devoting an important portion of her national budget was not enough to solve the shortage of teachers which the continually growing population made even more difficult. For instance, the population growth was up over 3 percent a year. ${ }^{6}$

1 BW10/11, op. cit, 1971, p. 2.

2 P. Rosillon, Atlas de la Langue Française, Paris : Bordas, 1995, p. 91.

3 Esprit, "La Politique Francaise de Coopération vis-à-vis de l'Algerie : Un Quiproquo Tragique", in Esprit, n² 208, Janvier 1995, p. 59.

4 A. T. Ibrahimi, De la Decolonisation à la Révolution Culturelle, Alger : SNED, 1973, p. 94.

5 lbid, p. 97.

6 BW10/11, op. cit, 1971, p. 1. 


\section{Conclusion}

The use of the French language has been historically, linguistically socially and practically an accepted reality among Algerians. In spite of the massive process of Arabisation, the proportion of the francophone population remained significant. The francophone population is in constant increase particularly as the current political administration does not block the private educational institutions, where the French language is taught even from the pre-school year, to grow and extend. Thus, if Algeria succeeded to obtain her political independence after seven years of bloody war, her linguistic independence requires a longer time of deep, hard, professional, objective and scientific work.

\section{Bibliography}

[1] BW10/11, Restricted, The British Council Algeria Representative's Annual Report 1969-70, 1970.

[2] BW10/11, Restricted, The British Council Algeria Representative's Annual Report 1970-71, 1971.

[3] BW10/11, Restricted, The British Council Algeria Representative's Annual Report 1972-73, 1973.

[4] BW10/11, Confidential, Visit to Algeria, April 24-- May 7,1963, Report by Mr. C. W, Fyfield - Representative Designate, 24 May 1963.

[5] Esprit, "La Politique Française de Coopération vis-à-vis de l'Algérie : Un Quiproquo Tragique", in Esprit, $n^{\circ} 208$, Janvier 1995.

[6] Crowder, M. (1962) Senegal : A Study in French Assimilation Policy, London : Institute of Race Relations.

[7] Carlier, 0., Colonna, F., Djeghloul, A. and El-Korso. M, Lettrés, Intellectuels et Militants en Algérie 1888-1950 (Alger : Office des Publications Universitaires : 04-88).

[8] Ibrahimi, A. T. (1973) De la Decolonisation à la Révolution Culturelle, Alger : SNED.

[9] Le Duc de Rovigo (Governor of Algeria 1832-33) "Je regarde la propagation de l'instruction et de notre langue comme le moyen le plus efficace de faire des progrès à notre domination dans ce pays". Quoted in Benrabah, M. (1999) Langues et Pouvoir en Algérie : Histoire d'un Traumatisme Linguistique, Paris : Edition Séguier.

[10] Rosillon, P. (1995) Atlas de la Langue Française, Paris : Bordas, 1995. 